
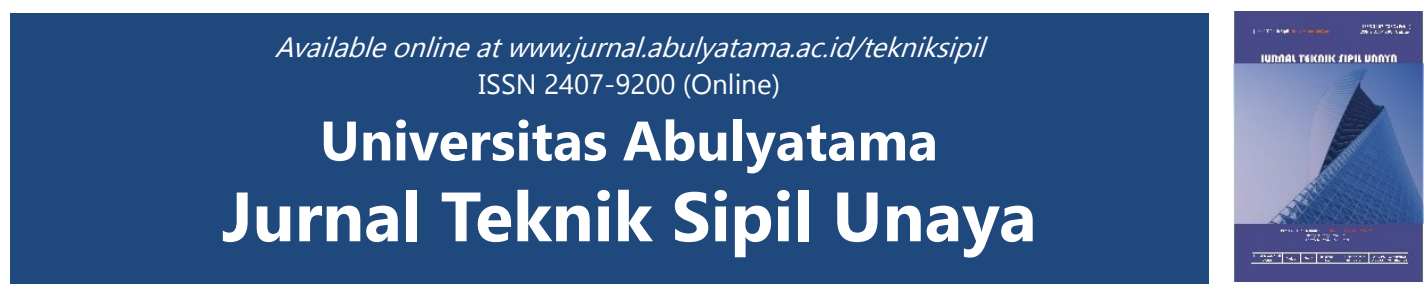

\title{
Pemodelan Kecepatan Arus dan Tinggi Gelombang Pada Rencana Breakwater Kolam Pelabuhan Meulaboh Dengan Menggunakan Program Delft3D
}

\author{
Ichsan Syahputra $^{1^{*}}$, Heny Yuliana ${ }^{2}$ \\ ${ }^{1}$ Program Studi Teknik Sipil Fakultas Teknik Universitas Abulyatama, 23372, Indonesia \\ ${ }^{2}$ Dinas Pengairan Aceh, Jl. Ir. Mohd. Taher No.18, Lueng Bata, Kota Banda Aceh, 23123, \\ Indonesia \\ *Email korespondensi : ichsansyahputra_sipil@abulyatama.ac.id
}

Diterima 19 April 2019; Disetujui 29 Juni 2019; Dipublikasi 31 Juli 2019

\begin{abstract}
The Meulaboh port in West Aceh Regency is one of the ports in the west coast of Aceh Province. Initial operation of this port began in 2016 and currently serves crossing activities with the Meulaboh - Sinabang pass. The Meulaboh port is located in open water facing the Indian Ocean. In extreme conditions, ships often have to delay shipping due to high waves that cause shocks to the ship. Based on these problems, the study will provide an overview of the impact and hydrodynamic response of the Meulaboh port pool area and analyze the impact of wave heights on activities in the port pond based on several Breakwater construction layout scenarios. Alternative handling scenarios are carried out using the Delft3D program. The distribution of wave height at the direction of the wind from the Southwest with $H s=4.908 \mathrm{~m}$, and $T s=7.254$ seconds which shows the dominant wave from the Southwest restrained by Breakwater and the wave height in front of the port mouth ranges from between 0-1 meters so it is safe against activities cruise.
\end{abstract}

\section{Keywords: Flow and Wave Modeling, Port, Delft3D Program.}

\begin{abstract}
Abstrak: Pelabuhan penyeberangan Meulaboh di Kabupaten Aceh Barat merupakan salah satu pelabuhan penyeberangan di wilayah pantai barat Provinsi Aceh. Pengoperasian awal pelabuhan ini dimulai pada tahun 2016 dan saat ini melayani aktifitas penyeberangan dengan lintasan Meulaboh - Sinabang. Pelabuhan penyeberangan Meulaboh berlokasi di perairan terbuka berhadapan dengan Samudera Hindia. Pada kondisi-kondisi ekstrim, seringkali kapal harus menunda pelayaran akibat tingginya gelombang yang mengakibatkan goncangan terhadap kapal. Berdasarkan permasalahan tersebut, maka penelitian akan memberikan gambaran terhadap dampak maupun respon hidrodinamika kawasan kolam pelabuhan Meulaboh dan menganalisis dampak tinggi gelombang terhadap aktifitas di kolam pelabuhan berdasarkan beberapa skenario tata letak konstruksi Breakwater. Pemodelan upaya penanganan dilakukan dengan menggunakan program Delft3D. Distribusi tinggi gelombang pada saat angin dari Barat Daya dengan Hs $=4.908$ $\mathrm{m}$, dan Ts $=7.254$ detik dimana gelombang dominan dari Barat Daya tertahan oleh Breakwater dan tinggi gelombang yang berada di depan mulut pelabuhan berkisar antara $0-1$ meter dengan demikian aman terhadap aktifitas pelayaran.
\end{abstract}

Kata kunci : Pemodelan Arus dan Gelombang, Pelabuhan, Program Delft3D. 
Pelabuhan penyeberangan Meulaboh di Kabupaten Aceh Barat merupakan salah satu pelabuhan penyeberangan di wilayah pantai Barat Provinsi Aceh. Pengoperasian awal pelabuhan ini dimulai pada tahun 2016 dan saat ini melayani aktifitas penyeberangan dengan lintasan Meulaboh - Sinabang. Keberadaan Pelabuhan Penyeberangan Meulaboh ini sangat mendukung kelancaran transportasi penyeberangan khususnya dalam memenuhi kebutuhan aktifitas masyarakat di Simeulue. Sebagai daerah kepulauan, Kabupaten simeulue sangat bergantung kepada angkutan penyeberangan dalam memenuhi kebutuhan sehari-hari. Penundaan operasional kapal menyebabkan permasalahan utama di lintasan menuju Simeulue yang berakibat kepada stagnanasi penumpukan barang, penumpang dan kendaraan di pelabuhan terkait. Pelabuhan penyeberangan Meulaboh berlokasi di perairan terbuka, dalam hal ini Samudera Indonesia. Kondisi ini sangat berpengaruh terhadap keselamatan dan kenyamanan pelayaran di pelabuhan ini. Pada kondisikondisi ekstrim, seringkali kapal harus menunda pelayaran akibat besarnya gelombang yang mengakibatkan goncangan terhadap kapal. Sedangkan kondisi ekstrim yang terjadi pada saat kapal akan berlabuh, bisa mengakibatkan kapal harus beralih ke pelabuhan terdekat, atau menjaga manuver kapal agar dapat berlayar dengan aman. Keadaan ini sangat mengganggu pelayanan kepada pengguna jasa pelabuhan penyeberangan Meulaboh. Kemudahan kapal dalam melakukan bongkar muat sangat dipengaruhi oleh ketenangan kondisi perairan, seperti arus, gelombang, angin serta pasang surut. Pengaruh kondisi perairan yang buruk akan menghalangi aktifitas kapal yang akan bersandar maupun berlabuh, yang berakibat secara tidak langsung kepada waktu tunggu maupun waktu bongkar muat di pelabuhan.

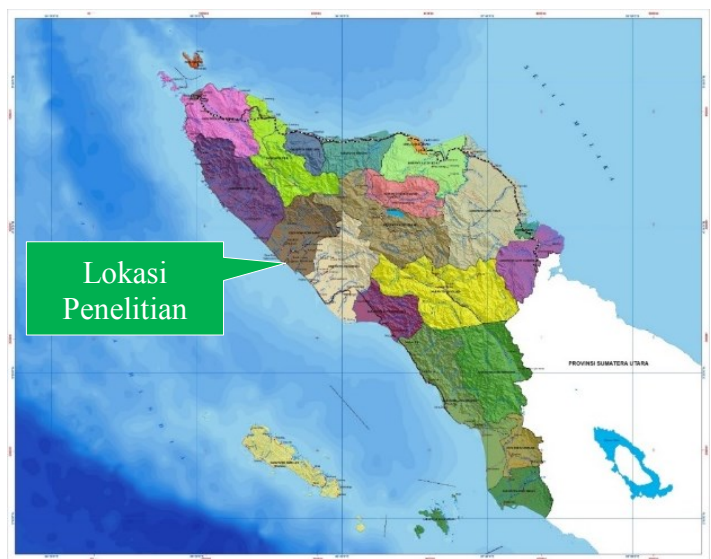

Gambar 1. Lokasi Penelitian

\section{KAJAN PUSTAKA}

\section{Hidro-Oceanografi}

Gambaran kondisi Hidro-Oseanografi meliputi pengumpulan dan pengolahan data pasang surut, pengumpulan data dan rekapitulasi data angin, prediksi kejadian gelombang, dan analisis gelombang yang diperhitungkan terhadap konstruksi.

\section{Gelombang Laut}

Gelombang yang terjadi di laut merupakan suatu pergerakan energi air laut yang diakibatkan oleh adanya tiupan angin, oleh karena itu dala peramalan kejadian gelombang diperlukan data angin. Data angin yang dipergunakan adalah hasil pencatatan dari Stasiun Meteorologi Bandara Cut Nyak Dhien, Kabupaten Nagan 
Raya. Data tersebut dipergunakan karena tidak adanya data pencatatan angin langsung di permukaan laut. Data angin nantinya akan dikonversikan menjadi data angin permukaan laut yang kemudian ditransformasikan menjadi data gelombang.

\section{Kecepatan Angin}

Data angin rata-rata diperlukan untuk mengetahui arah dominan dari gelombang dimana data angin digunakan untuk memprediksikan gelombang. Data angin rerata harian diplot dalam sebuah tabel persentase dimana kecepatan angin diklasifikasikan dalam empat kelompok angin dari 0 - 9 knot dan dibagi berdasarkan arah angin.

\section{Pasang Surut}

Pengamatan pasang surut dimaksudkan untuk mendapatkan muka air laut rata-rata (MSL) maupun yang lainnya dan nilai konstanta dari komponen-komponen pasang surut (amplitude dan beda fasa). Pengamatan pasang surut dilaksanakan dengan menggunakan palem atau Vawe Pole. Pengamatan pasang surut dilaksanakan secara kontinyu selama 30 hari dimana dilakukan secara visual dengan waktu minimal 1 (satu) piantan atau kira-kira 24 (dua puluh empat) jam secara berturut-turut dengan interval waktu setiap 1 (satu) jam.

\section{Gelombang Rencana}

Menurut Triatmodjo (1999), peramalan gelombang dimaksudkan mengalih ragamkan (transformasi) data angin menjadi data gelombang. Mengingat kurangnya data gelombang di Indonesia, maka untuk keperluan perencanaan bangunan pantai sering digunakan data angin untuk peramalan gelombang. Data angin yang digunakan untuk daerah studi di Kuala Bubon Meulaboh berasal dari Stasiun BMKG Cut Nyak Dhien, Nagan Raya.

Berdasarkan data representatif untuk beberapa tahun pengamatan dapat diperkirakan gelombang yang diharapkan disamai atau dilampaui satu kali dalam $\mathrm{T}$ tahun, dan gelombang tersebut dikenal dengan gelombang periode ulang $\mathrm{T}$ tahun atau gelombang $\mathrm{T}$ tahunan. Misalnya apabila $\mathrm{T}=25$, gelombang yang diperkirakan adalah gelombang 25 tahunan atau gelombang dengan periode ulang 25 tahun, artinya bahwa gelombang tersebut diharapkan disamai atau dilampaui rata-rata sekali dalam 25 tahun. Hal ini tidak berarti bahwa gelombang 25 tahunan hanya akan terjadi satu kali dalam setiap periode 25 tahun yang berurutan; melainkan diperkirakan bahwa gelombang tersebut jika dilampaui $\mathrm{k}$ kali dalam periode panjang $\mathrm{M}$ tahun akan mempunyai nilai $\mathrm{k} / \mathrm{M}$ yang kira-kira sama dengan $1 / 50$.

\section{Pemodelan Numerik}

Secara umum, penelitian ini dilakukan dengan beberapa cara yaitu melalui pemodelan numerik untuk melihat pola arus dan pasang surut, melalui penggunaan rumus eksperimental untuk mendapatkan data tinggi gelombang, dan melalui pengukuran lapangan untuk menganalisis dari validasi model numerik yang dilakukan. Proses ini dilalui untuk diperoleh data pembanding dari hasil pemodelan dengan kondisi sesungguhnya di lapangan terutama pada 
saat kondisi pasang surut. Sebagaimana dipahami bahwa pemodelan numerik telah melalui beberapa proses penyederhanaan dari keadaan alam ke dalam sejumlah formula matematika. Penyederhanaan tersebut dapat berimplikasi terhadap akurasi data. Beberapa studi sensitivitas pemodelan numerik membuktikan bahwa beberapa proses penyederhanaan akan memberikan dampak terhadap akurasi hasil pemodelan jika dibandingkan dengan data lapangan.

Dalam pemodelan arus dan gelombang menggunakan program Delft3D sebagai alat untuk perhitungan yang terdiri dari Delft3D Flow dan Delft3D Wave. Delft3D-Flow adalah sistem pada bagian Delft3D yang digunakan untuk menghitung SWE (Shallow Water Equation) atau persamaan pada kondisi air dangkal dalam variabel kecepatan dan tinggi ke dalam bentuk dua atau tiga dimensi pada sebuah grid. Grid adalah garis bantu koordinat arah vertikal dan horizontal untuk menentukan luas daerah yang dimodelkan atau untuk mengatur batas daerah yang dihitung. Grid terdiri dari dua sistem yaitu coordiante cartessian berbentuk persegi dan coordinate spherical.
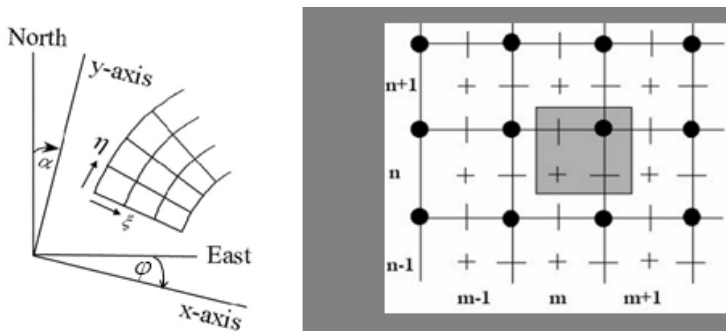

Gambar 2. Sistem koordinat spherical dan sistem koordinat cartessian
Sistem coordinate cartessian berbentuk persegi, bersifat kaku dan hanya mempunyai parameter arah saja, yaitu arah vertikal $(\eta)$ dan arah horizontal $(\xi)$. Sedangkan sistem coordinate spherical mengikuti garis kontur permukaan bumi. Coordinate spherical memiliki dua parameter yaitu arah dan tinggi, dengan latitude $(\theta)$ bernilai positif ke arah utara dan longitude $(\phi)$ yang bernilai positif ke arah timur (Anonim, 2007).

Delft3D-Flow terdiri dari 7 bagian yang memiliki fungsi sebagai berikut:

- Delft3D-Rgfgrid : Membuat zona segmen dalam bentuk grid pada topografi;

- Delft3D-Triana : Analisis pasang surut dalam interval waktu;

- Delft3D-Tide : Analisis pasang surut terhadap water level dan kecepatan;

- Delft3D-QuickIn : Masukan output pada grid berupa data batimetri, asukan output pada grid berupa data batimetri, kondisi awal untuk waterlevel, salinitas dan lainnya;

- Delft3D-Nesthd : Membuat batasan dari keseluruhan model;

- Delft3D-Gpp : Menampilkan hasil berupa animasi;

- Delft3D-Quickplot : Sama halnya dengan Delft3D-Gpp.

\section{METODE PENELITIAN}

\section{Hidro-Oceanografi}

Analisis hidro-ocenografi ini disajikan berdasarkan data-data sekunder berupa rentang pasang surut dan pembangkitan data gelombang dari data angin yang diperoleh dari stasiun 
pengamatan terdekat. Selanjutnya, simulasi gelombang dan arus dilakukan dengan menggunakan piranti lunak DELFT3D yang merubah wilayah pelabuhan menjadi dua dimensi horizontal (SDH). Piranti lunak DELFT3D ini mengadopsi persamaan differensial parsial dimana persamaan Navier Stokes dua dimensi di-diskretisasi secara explisit. Wilayah hitung (domain) simulasi mencakup luasan yang memadai yang meliputi seluruh komponen pada pelabuhan Meulaboh ditambah wilayah untuk Open Boundary yang juga mencakup alur masuk kolam pelabuhan.

\section{Program Delft3D}

Delft3D adalah salah satu software yang dikembangkan oleh deltares sebagai suite perangkat lunak komputer terpadu yang unik untuk Multi-Disiplin. Pendekatan dan perhitungan di daerah pesisir, sungai dan muara dapat dilakukan simulasi arus, transport sedimen, gelombang, kualitas air, perkembangan morfologi, dan ekologi. Adapun Delft3D-FLOW manual salah satu dari modul ini adalah simulasi hidronamika multi deimensi (2D dan 3D), program yang menghitung fenomena aliran dan arus yang dihasilkan dari pasang surut dan Meteorolgi yang memaksa pada persegi panjang atau lengkung, grid yang dipasang batas untuk mencapai pendekatan koordinat.

Pada pemodelan Delft3D ini, menggunakan grid dalam bentuk coordinate cartessian berbentuk persegi. Pembutan grid ini dengan menggunakan program Delft3D-RGFGRID, tujuan program ini adalah untuk membuat grid, memodifikasi, dan menvisualisasikan ortogonal untuk Delft3D-FLOW dan Delft3D-WAVE

(Anonim, 2007c). Pada kajian ini mengklasifikasikan grid kedalam tiga model ukuran berdasarkan faktor yang ditinjau, yakni jarak grid $(\Delta \mathrm{x}$ dan $\Delta \mathrm{y})$ satu sama lain sebesar 10 x $10 \mathrm{~m}$.
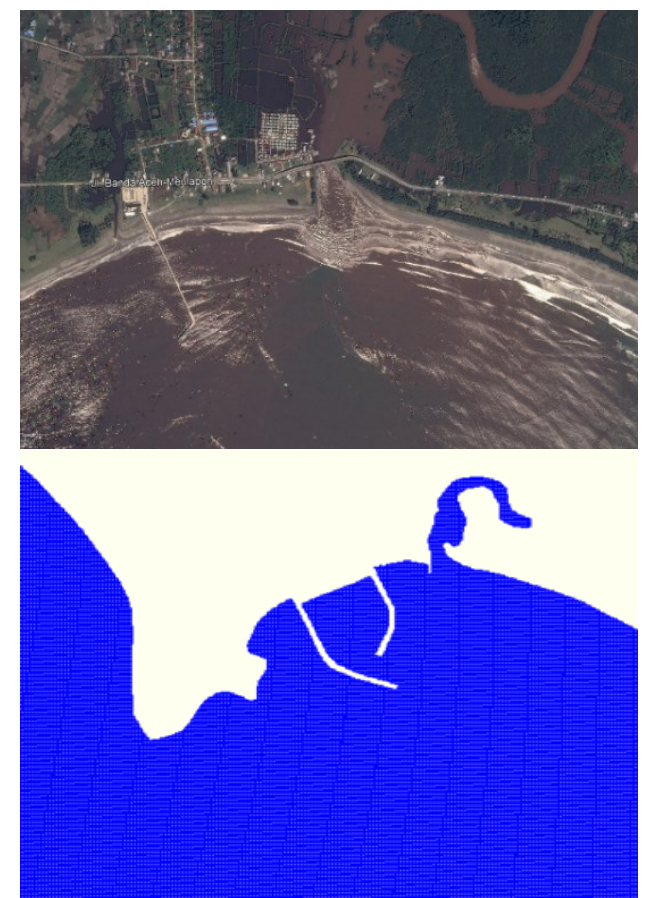

Gambar 3. Citra Satelit dan Grid Pemodelan

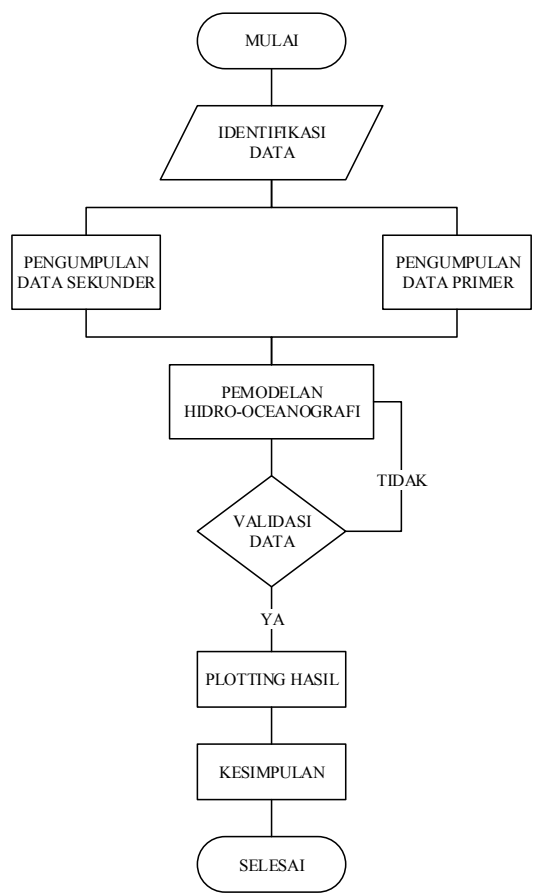

Gambar 4. Bagan Alir Pemodelan 


\section{HASIL DAN PEMBAHASAN}

\section{Kondisi Eksisting}

Berdasarkan hasil tinjauan di lokasi Pelabuhan Penyeberangan Meulaboh dapat diinformasikan hal-hal penting terkait dengan permasalahan yang terjadi sebagai berikut :

1) Pelabuhan Penyeberangan Meulaboh adalah pelabuhan tipe Jetty yang strukturnya menjorok ke laut dan secara geografis menghadap langsung ke Samudera Hindia dan berada di perairan dangkal dampak laju sedimentasi dan di beberapa titik lokasi merupakan zona karang;

2) Pelabuhan Penyeberangan Meulaboh berada di sebuah teluk yang merupakan cekungan dalam sehingga proses sedimentasi di sepanjang garis pantai terutama juga di pengaruhi oleh Krueng Woyla, Krueng Teunom di Kabupaten Aceh Jaya dan Krueng Meureubo di Kabupaten Aceh Barat akan cepat terjadi dan menambah kontribusi sedimentasi di pelabuhan;

3) Kecepatan angin di lokasi pelabuhan relatif tinggi sehingga dapat berpengaruh terhadap aktifitas pelayaran;

4) Arah angin dominan dari Barat Laut dan posisi dermaga sandar kapal sudah cocok namun akan berpengaruh kepada kekuatan lantai depan pada saat menurunkan dan menaikan kendaran termasuk keselamatannya;

5) Perkiraan penyelesaian permasalahan di Pelabuhan Penyeberangan Meulaboh adalah :

a) Pembuatan bangunan pemecah gelombang (Breakwater) berupa

kolam pelabuhan dengan tujuan dapat meredam energi dari gelombang yang selama ini menggangu aktifitas pelayaran.

b) Pembuatan bangunan penangkap/penghambat laju sedimen (Goin) yang ditempatkan tegak lurus garis pantai sebagai bangunan pengaman pantai dari gerusan akibat adanya bangunan Breakwater sehingga permukiman dan aktifitas masyarakat nelayan setempat tidak terganggu.

\section{Pasang Surut}

Pengamatan pasang surut di Pelabuhan Penyeberangan Meulaboh dilakukan selama 30 (tiga puluh hari) dengan interval waktu setiap 1 jam yang berlokasi di PPI Kuala Bubon. Dipilih lokasi ini karena kondisi perairannya lebih tenang dibandingkan lokasi yang lain.

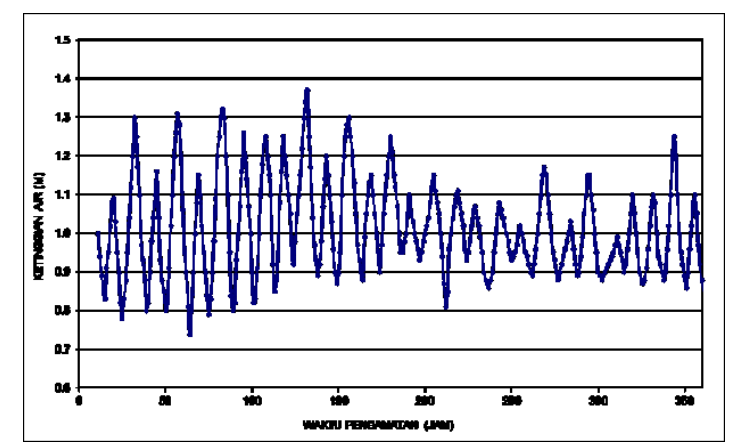

Gambar 5. Grafik Pengamatan Pasang Surut

\section{Kecepatan Angin}

Kecepatan angin rata-rata harian diplot dalam sebuah tabel persentase dimana kecepatan angin dibagi berdasarkan arah angin. Hal ini dilakukan karena jumlah data kecepatan 
angin untuk beberapa tahun pengukuran relatif banyak. Prosentasi tertinggi kecepatan angin dominan sebesar $31.13 \%$ terjadi dari arah Barat Daya. Tinggi gelombang signifikan sebesar $4.908 \mathrm{~m}$ dan periode gelombang signifikan selama $7.254 \mathrm{~m} /$ detik.

\section{Pemodelan Arus dan Gelombang}

Wilayah pemodelan untuk kajian ini difokuskan pada area sekitar muara Kuala Bubon dengan peta lokasi sebagaimana telah disampaikan di atas. Ukuran total dari wilayah yang dimodelkan sekitar $2 \mathrm{~km}$ sejajar pantai dan $3 \mathrm{~km}$ tegak lurus pantai. Setelah pembuatan grid selesai dilakukan, selanjutnya pada setiap grid tersebut diberikan nilai kedalaman dengan menggunakan modul Delft3D-QUICKIN. Untuk input data kedalaman di laut diasumsikan dengan tanda positif sedangkan input data elevasi di darat diasumsikan dengan tanda negatif.

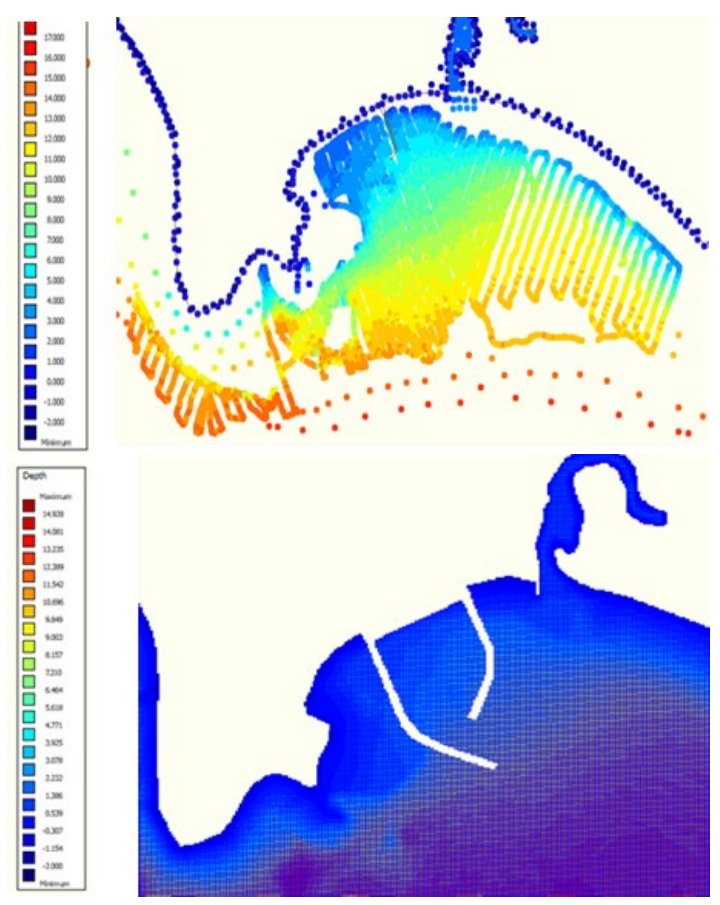

Gambar 6. Nilai Kedalaman Dalam Pemodelan Sebelum dan Sesudah Interpolasi

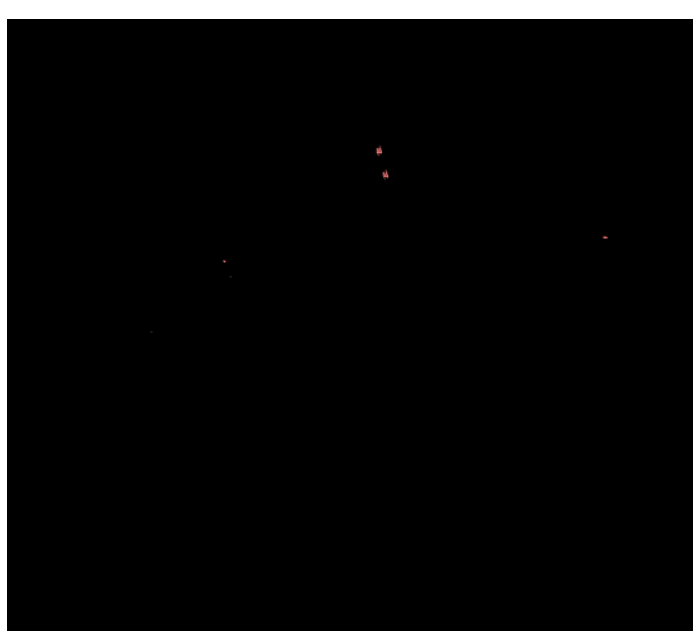

Gambar 7. Tata Letak Rencana Breakwater

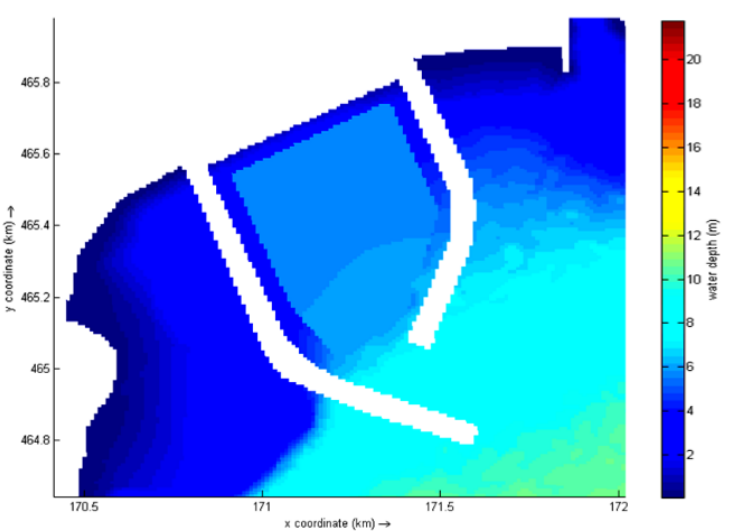

Gambar 8. Kondisi Kedalaman Perairan

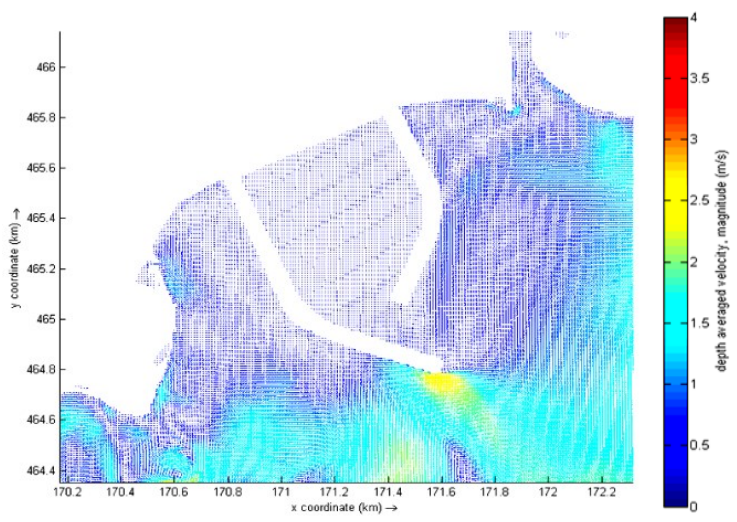

Gambar 9. Sebaran Vektor Kecepatan Arus

Pemodelan di atas menunjukkan kondisi arus di mulut kolam pelabuhan relatif tenang dengan kecepatan berkisar antara $0.2-0.5 \mathrm{~m} / \mathrm{det}$ dan arus dominan juga tertahan oleh sisi dari Breakwater pelabuhan. 


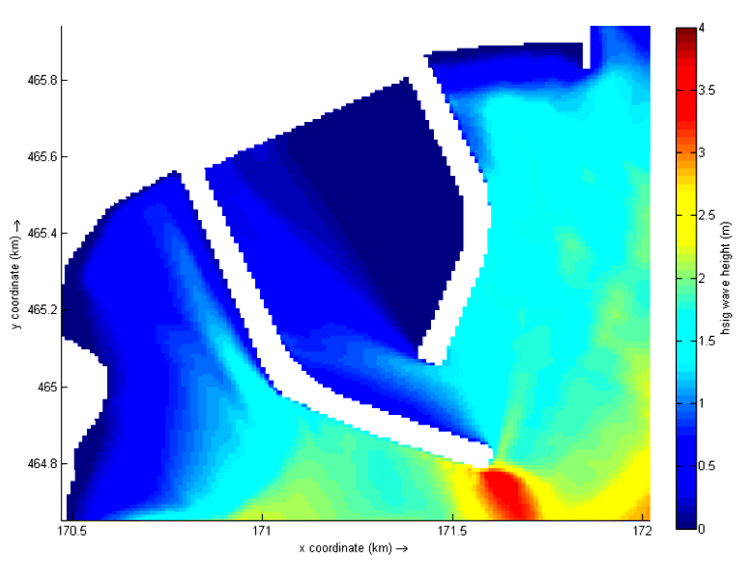

Gambar 10. Distribusi Tinggi Gelombang

Pemodelan di atas menunjukan gelombang dominan dari Barat Daya tertahan oleh Breakwater (tidak masuk ke dalam kolam pelabuhan) dan tinggi gelombang yang berada di depan mulut pelabuhan berkisar antara $0-1$ meter.

\section{KESIMPULAN DAN SARAN}

\section{Kesimpulan}

1) Kecepatan arus dan tinggi gelombang di sekitar peraian Kuala Bubon sangat mempengaruhi aktifitas pelayaran Pelabuhan Meulaboh.

2) Angin maksimum dari arah Barat Daya dengan prosentasi angin dominan sebesar $31.13 \%$, dimana nilai $\mathrm{Hs}=4.908 \mathrm{~m}$, dan $\mathrm{Ts}$ $=7.254$ detik.

3) Kondisi arus di dalam pelabuhan kolam relatif tenang, kondisi arus di mulut kolam pelabuhan juga tenang dengan kecepatan berkisar antara $0.2-0.5 \mathrm{~m} / \mathrm{det}$ dan arus dominan tertahan oleh Breakwater.

4) Distribusi tinggi gelombang hasil dari pemodelan menunjukan gelombang dominan dari Barat Daya tertahan oleh
Breakwater (tidak masuk ke dalam kolam pelabuhan) dan tinggi gelombang yang berada di depan mulut pelabuhan berkisar antara $0-1$ meter.

\section{Saran}

1) Perlunya kajian lanjutan mengenai laju sedimentasi sepanjang pantai dan kemungkinan masuknya ke dalam kolam pelabuhan;

2) Perlunya kajian mendalam dan terpisah untuk mengestimasi volume sedimen pasca selesainya konstruksi pelabuhan apabila dibangun mengingat pada kajian saat ini masih menggunakan beberapa data sekunder untuk seluruh domain simulasi;

3) Perlu direncanakannnya proses keruk kolam dan alur masuk pelabuhan dengan interval waktu keruk antara 3 tahun hingga 4 tahun dan pengerukan disarankan difokuskan pada daerah sekitar mulut kolam pelabuhan saja;

4) Perlu dilakukannya monitoring terhadap elevasi dasar laut/kolam pelabuhan, sehingga bisa disimpulkan kapan harus dilakukannya pengerukan untuk menjaga kualitas dan aktifitas pelabuhan.

\section{UCAPAN TERIMAKASIH}

Penulis mengucapkan terima kasih kepada pihak-pihak yang telah membantu dalam pelaksanaan Penelitian ini terutama kepada Dinas Perhubungan Aceh dan PT. Hidroteknik Andalan, semoga dengan hasil Penelitian ini dapat membantu dalam perencanaan dan pembangunan Breakwater Kolam Pelabuhan Penyeberangan Meulaboh. 


\section{DAFTAR PUSTAKA}

Bambang Triatmodjo. (1999). Teknik Pantai.

Yogyakarta: Beta Offset.

Bambang Triatmodjo. (2007). Pelabuhan.

Yogyakarta: Beta Offset.

Bambang Triatmodjo. (2010). Perencanaan

Pelabuhan. Yokyakarta: Beta Offset.

Bambang Triatmodjo. (2012). Perencanaan

Bangunan Pantai. Yogyakarta: Beta Offset.

CERC. (1984). Shore Protection Manual, US

Army Coastal Engineering Research

Center, Washington.

Departemen of The US Army Corps of Engineer

(US Army). (2002). Design Of Coastal

Revetments, Seawalls, and Bulkheads,

Washington.

Dinas Perhubungan Aceh. (2018). DED

Pembangunan Breakwater Pelabuhan

Penyeberangan Meulaboh. Banda Aceh.

Hidroteknik Andalan. (2018). DED

Pembangunan Breakwater Pelabuhan

Penyeberangan Meulaboh. Banda Aceh.

Kementerian Perhubungan.

(2004).

Penyelenggara Pelabuhan Penyeberangan.

Jakarta.

Nyoman Budiartha. (2015). Perencanaan dan

Perancangan Konstruksi Bangunan Laut dan Pantai. Arti Foundation.

Pasific Consultants, Qualification and Experience in Ports and Harbors. Tokyo.
Pemerintah Aceh. (2015). Rencana Induk Pelabuhan (RIP) Penyeberangan Meulaboh Kabupaten Aceh Barat. Banda Aceh.

U.S. Army Corps of Engineer. (2002). Coastal Engineering Manual. Washington.
- How to cite this paper :

Syahputra, I., \& Yuliana, H. (2019). Pemodelan Kecepatan Arus dan Tinggi Gelombang Pada Rencana Breakwater Kolam Pelabuhan Meulaboh Dengan Menggunakan Program Delft3D. Jurnal Teknik Sipil Unaya, 5(2), 59-67 